\title{
THE SUBMICROSCOPIC STRUCTURE OF ARTICULAR CARTILAGE IN SWINE IN THE EARLY POSTNATAL PERIOD
}

\author{
D. HORKÝ \\ Department of Anatomy, Histology and Embryology, University of Veterinary Science, 61242 Brno
}

Received October 11, 1989

\begin{abstract}
Horký D.: The Submicroscopic Structure of Articular Cartilage in Swine in the Early Postnatal Period. Acta vet. Brno 60, 1991: 323-334.

The study was concerned with articular cartilage of the femoral heads in 4 pigs of both sexes at 2 days after birth. The tissue specimens were observed by light microscopy and by transmission and scanning electron microscopy.

The surface layer of the cartilage was made up of spindle-shaped chondrocytes arranged in two rows. The chondrocytes sent out long projections into the surrounding intercellular matter in which pericellular and intercellular matrix were distinguished. The Golgi apparatus was well developed and cytoplasmic inclusions were distinct and numerous.

Chondrocytes of the middle layer were oval in shape and measured 9 by $6 \mu \mathrm{m}$. They contained large amounts of cytoplasm with the Golgi apparatus distributed into several fields; they were rich in mitochondria, granular endoplasmic reticulum, glycogen and lipid droplets. This layer showed the presence of regular cilia and occasional passage of collagen protofibrils through the cell membrane. A clear distinction between pericellular and intercellular matrix was apparent.

The zone between the middle and the deep layers showed transitional type chondrocytes. Cells of the deep layer were made into columns situated perpendicular to the surface; they did not differ from the chondrocytes of the corresponding layer in adult animals.

The cartilage surface at 2 days of age was coated with a chondrosynovial membrane. Below this, about $1 \mu \mathrm{m}$ deep, collagen fibrils running perpendicular to each other produced a solid surface layer capable of resisting to pressure and facilitating movement of the joint.
\end{abstract}

Swine, age, joint, cartilage, submicroscopic structure

Hyaline articular cartilage, a major part of the synovial articulation, is largely involved in mechanical function and it is evident that to ensure proper joint functioning it has to meet two principal requirements: it must resist pressure and facilitate sliding and lubrication of the areas of contact (Wright 1969; Freeman and Kempson 1973; Maroudas 1971; Chappuis et al. 1983; Swann et al. 1984).

Cartilage is adapted to resist pressure by the structure and arrangement of the two components of the intercellular matter (Weis et al. 1968; Clarke 1974; Bloebaum and Wilson 1980; Horký 1980; Ghadially 1983; O'Connor 1980). Chondrocytes have only a minor part in the mechanics of joint movement (Maroudas 1973) but play a key role in the synthesis of intercellular matter responsible for mechanical properties (Maroudas 1973; Ghadially 1983; Palmoski and Brandt 1984).

Articular cartilage arises from mesenchyma, as a part of cartilaginous blastema of the bone rudiment, during the development of the skeleton. Although the pre-formed bone rudiment is gradually eroded, neither this process nor the following ossification affect the articular cartilage which remains present on the articular surfaces (Bonucci 1967; Hanaoka 1976).

The process of mesenchyma condensation in the blastema takes place in the early embryonic development. Gardner and O'Rahilly (1968) report that in man at about 6 weeks after fertili- 
zation the chondrification of the femur is commenced and at 8 weeks the articular cavity appears as a differentiated groove produced by mesenchymal blastema of the bone rudiment (Ghadially 1983). Data on the differentiation of articular cartilage in lower mammals have not been published. The differentiation changes resulting in the formation of articular cartilage before birth and leading to the final appearance of the specialized tissue after birth are referred to as the maturation process. They are determined by genetic, endocrinologic and nutritional factors (Silberger et al. 1961) and, particularly in the postnatal period, by environmental factors (Ghadially 1981, 1982; Perrin et al. 1978). Alterations in the morphology of articular cartilage are mostly due to ageing processes. They have been described in detail in mice (Silberger et al. 1976), rats (Mark et al. 1989), rabbits (Davies et al. 1962; Barnett et al. 1963), dogs (Lust et al. 1972; Lust and Sherman 1973; Wiltberger and Lust 1975; Fife 1982), cattle (Horký 1983; Neame et al. 1989; Kiefer et al. 1989), man (Horký 1980; Ghadially 1983) and also in pigs (Grondalen 1974c, f; Nakano et al. 1979). However, only a single paper on the ultrastructure of articular cartilage in swine (Bhatnagar et al. 1981) is available and the study was limited only to animals 20 to 30 weeks old. Some ultrastructural studies are concerned with pathological changes at the lumbosacral junction (Doige 1980) or describe the growth plate in animals at different ages (Nakano et al., 1982; Farnum et al. 1984). Since the ultrastructure of articular cartilage in the young pig has so far received little attention, our investigation was focused on the early postnatal period with the objective to complete the existing data.

\section{Materials and Methods}

Articular cartilage was collected from the caput ossis femoris of 4 animals of both sexes at 2 days after birth and processed for observation by light, transmission and scanning electron microscopy.

For transmission electron microscopy, the specimens were further dissected to obtain strips measuring 1 by 1 by $3 \mathrm{~mm}$ which were immediately fixed in glutaraldehyde solution ( $300 \mathrm{mmol} / 1$ or $400 \mathrm{mmol} / \mathrm{l}$ ) in phosphate buffer, $\mathrm{pH} 7.4$. This was followed by rinsing in $0.1 \mathrm{M}$ phosphate buffer ( $\mathrm{pH} \mathrm{7.4),} \mathrm{in} 4$ consecutive baths applied for $30 \mathrm{~min}$. each, and fixation with an $\mathrm{OsO}_{4}$ solution ( $40 \mathrm{mmol} / \mathrm{l}$ ) in phosphate buffer (pH 7.4) for $60 \mathrm{~min}$. Dehydration, immersion and embedding in Durcupan ACM were routine procedures. Ultrathin sections were cut with an Ultracut Reichert ultramicrotome and stained with either lead citrate alone or uranyl acetate combined with lead citrate. The sections were studied and photographed with a Tesla BS 500 electron microscope. The embedded material was also used to prepare semithin sections for light microscopy observation. These were stained with methylene blue and Azure II.

\section{Results}

The articular cartilage in the age category studied had already acquired some signs of fully differentiated tissue. With progressing differentiation (Horký 1988) both chondrocytes and intercellular matter attained some characteristics which permitted distinction of 3 parts: the surface, the middle and the deep layers.

\section{Submicroscopic structure of surface layer chondrocytes}

These chondrocytes were arranged in two rows above each other. They differed in both size and appearance. Close to the surface were small spindle-shaped cells, measuring about 5 by $2 \mu \mathrm{m}$ in cross sections (Plate VII., Fig. 1). The cells ran strictly parallel to the articular surface. They were considerably flattened and had multiple long cytoplasmic projections extending into the surrounding matrix which formed a broad lining composed of the ground amorphous substance and aperiodic fibrils (Fig. 1). In fact, this region was the pericellular matrix which prevailed due to poorly developed intercellular matrix and unusually extended lacunae. The chondrocytes, by their ultrastructural characteristics, were strongly reminiscent of the cells in the surface zone of the articular cartilage in the pig at 94 days after fertilization (Horký 1988).

Chondrocytes of the other type were found deeper in the surface layer of the 
articular cartilage. They were elongated with rounded tips and their size was about 5.8 by $4 \mu \mathrm{m}$ (Plates VIII., IX., Figs 2, 3, 4).

\section{Nucleus}

The shape of the nucleus resembled a rod or a horseshoe (Figs 2,3). The nuclear envelope with a typical appearance extended against the karyoplasm in either broad, shallow in aginations (Fig. 2) or deep grooves (Fig. 3). Nuclear chromatin was aggregated into large karyosomes attached to the nuclear envelope and forming a continuous layer broken only by nuclear pores or chromatin canals (Figs 2,3). Most of the nuclear region seen on cross section was filled with diffuse chromatin and appeared markedly light. Nucleoli were a rare finding.

\section{Cytoplasm}

The granular endoplasmic reticulum presented as rather short and frequently branched cisternae (Figs 3,4 ) placed in the cytoplasm close to both cell poles. The cisternae were narrow and invariably contained filamentous medium electron-dense material.

The agranular endoplasmic reticulum was seen as small vesicles most probably derived from the Golgi apparatus cisternae.

The Golgi apparatus found in the cytoplasm of these cells was well developed. It consisted of several Golgi fields which contained typical dictyosomes and their derivates, i. e., small and large Golgi vacuoles. The apparatus took up a considerably large area of the cytoplasm (Fig. 2). Some of the vacuoles were filled with either filamentous, particulate or homogeneous material so that they resembled transport vacuoles or, less frequently, secondary lysosomes (Figs 2,3).

Mitochondria, typical in structure and size, were few in number. Their matrix mitochondrialis did not show any granules. Most of the mitochondria were found at the cell periphery next to the cell membrane (Figs 3,4 ).

The cell membrane. The cytoplasm in these cells sent out only short, unbranched projections, 0.8 to $1.0 \mu \mathrm{m}$ in size, into the pericellular matrix. Generally, the projections contained only ground cytoplasm and occasional ribosomes (Figs $2,3,4)$. Pinocytotic vesicles were found rarely (Fig. 3).

Glycogen was a regular finding in the cytoplasm of chondrocytes of this type. It was either dispersed as single alpha granules or formed small rosettes (Figs 2,3) irregularly scattered among the organelles. In some of the chondrocytes it made large deposits close to one of the cell's poles (Fig. 4).

Fine bundles of intracytoplasmic filaments were found mostly at the peripheries of the cells (Figs 2, 3, 4).

\section{Submicroscopic structure of middle layer chondrocytes}

Chondrocytes of the middle layer presented as cells with an irregular oval shape and a size of 9 by $6 \mu \mathrm{m}$.

\section{Nucleus}

The size of the nucleus was about $4 \mu \mathrm{m}$ and its shape followed that of the cell (Plates X., XI., Figs 6, 7, 8). The nuclear envelope produced very shallow invaginations. In the regions where cytoplasmic inclusions, lipid droplets in particular, were aggregated the nuclear envelope was deeply immersed in the karyoplasm (Fig. 6). Chromatin was seen as either a continuous layer, varying in width, along the inner membrane or occasional karyosomes in cross sections through the nucleus or clusters of perinucleolar chromatin situated near a compact nucleolus. 
Nuclear pores were numerous (Figs 6,7). The zonula nucleum limitans had the usual appearance.

Cytoplasm

The nucleocytoplasmic ratio in middle layer chondrocytes was shifted in favour of the cytoplasmic component.

The granular endoplasmic reticulum was present in larger amounts than in the cells of the surface layer. It produced long cisternae and short bag-shaped formations which were branched and dilated (Figs 6, 7, 8). All parts of the granular endoplasmic reticulum were filled with filamentous medium electron-dense material. The reticular membranes were densely covered with ribosomes.

The agranular endoplasmic reticulum presented as occasional smooth vesicles found in the close vicinity of the cell membrane (Figs $6,7,8$ ) or in the areas of glycogen deposits (Fig. 7). This finding suggests an involvement of the agranular reticulum in glycogen metabolism.

The Golgi apparatus in chondrocytes of the middle layer was a rich and well developed complex. Its structures were distributed over several Golgi fields taking up a large part of the cytoplasm (Figs $6,7,8$ ). It was made up of typical dictyosomes whose cisternae segregated numerous small and large Golgi vesicles into the surrounding cytoplasm. The large vesicles contained filamentous material and were, in fact, the typical transport vacuoles. Cross-sectioned filaments had a typical appearance of protocollagen fibrils (Figs 7, 8). Small Golgi vesicles were electron-transparent and constituted the fundamental part of the agranular endoplasmic reticulum.

Mitochondria occurred frequently. They showed the usual structure but attained a length of up to $2 \mu \mathrm{m}$. In some of them the matrix was clear (Fig. 8) and occasionally their crists were dilated (Fig. 6).

Lysosomes were a rare finding. If seen at all, they presented as small secondary lysosomes resembling dense bodies (Figs 6, 7).

Centrioles were found regularly in the cytoplasm of the middle layer chondrocytes (Fig. 7). Most frequently, they were present at the peripheries of the cells and showed the usual structure. Cross sections revealed that close to the centrioles there were bands of dark material reminiscent of pericentriolar structures referred to as satelites (Fig. 7). Cilia were not observed in these cells.

Cell membrane. The cytoplasm produced short, non-branched projections which were cone- or ring-shaped (Figs $6,7,8$ ) and up to $2 \mu \mathrm{m}$ in length. The projections contained only ground cytoplasm and occasional ribosomes. Some of them were penetrated with fine bundles of intracytoplasmic filaments. Pinocytotic vesicles were very rare (Fig. 6). In some of the cells it was noted that the cell membranes of the cytoplasmic projections were penetrated with collagen fibrils (Fig. 8).

Glycogen occurred regularly as small clusters of alpha granules in the cytoplasm (Fig. 7); larger deposits were found only rarely (Fig. 6).

Lipid droplets were accumulated at one of the cell's poles and presented as a cluster of vacuoles, up to 1 by $3 \mu \mathrm{m}$ in size, with glycogen in their vicinity (Fig. 6).

\section{Submicroscopic structure of the deep layer chondrocytes}

The cells of the deep layer were smaller than those of the middle layer. They were lying more or less parallel to the surface forming typical columns perpendicular to the surface. Single oval cells occurring in the zone between the middle 
and deep layers usually measured 8 by $4 \mu \mathrm{m}$ (Plate XII., Fig. 9) and the cells composing the columns were 5 by $3 \mu \mathrm{m}$ (Fig. 10).

The nucleus was oval in shape, with chromatin forming karyosomes of the usual arrangement. The nuclear envelope had a typical structure, invaginations were shallow (Fig. 9). Nuclear pores were infrequent. The zonula nucleum limitans made a narrow homogeneous lining at the nuclear envelope. The nucleolus was a rare finding; if observed at all, it was of reticular type.

Cytoplasm

The granular endoplasmic reticulum consisted only of short flattened cisternae distributed at the periphery of the cell and among the organelles (Fig. 1). The content of the cisternae aid not differ from that of the chondrocytes composing the middle layer.

The agranular endoplasmic reticulum was found only occasionally.

The Golgi apparatus involved a small cytoplasmic region; it comprised several smooth cisternae and small vesicles. Its structures, as well as its derivatives, were discernible on rare occasions.

Mitochondria were infrequent. They measured 0.5 by $0.8 \mu \mathrm{m}$, had the usual structure and contained dense matrix with no clearing (Fig. 9).

Ribosomes were either attached to the membranes of the granular endoplasmic reticulum or freely dispersed as monosomes mainly in the cytoplasm of the cells forming the columns.

Neither centrioles nor cilia were detected in the chondrocytes of the deep layer.

If any lysosomes were present in this layer, they were always secondary lysosomes. The cytoplasm of chondrocytes in the zone bordering the medium and deep layers included conspicuous electron-dense bodies consisting of homogeneous material and each bounded with a smooth membrane (Fig. 9). Some of these attained a large size of about 0.8 by $1.0 \mu \mathrm{m}$, some measured only 0.1 to $0.3 \mu \mathrm{m}$ and some looked like pseudomyeline structures (Fig. 9). Cells composing the columns did not contain these structures.

Cell membrane. Cytoplasmic finger-shaped projections were seen around the cells; smooth surfaces were only in areas of cell contact (Fig. 10). The projections were short, not exceeding $1 \mu \mathrm{m}$, and did not branch. They extended into the surrounding pericellular matrix. Pinocytotic vesicles were present only occasionally (Figs 9, 10).

Glycogen was a regular finding in the cytoplasm of cells forming the columns. It presented as small clusters of alpha granules (Fig. 10) in amounts smaller than was found in the middle layer chondrocytes.

Lipid droplets were present in low quantities. They measured up to $1 \mu \mathrm{m}$ and were usually found close to glycogen deposits (Fig. 10).

Intracytoplasmic filaments showed an arrangement similar to that observed in the cytoplasm of middle layer chondrocytes.

\section{Intercellular matter}

In the period of embryonic development studied, the intercellular matter, i. e., its fibrillar and interfibrillar components, had the signs of organization which, both in structure and in quality, resembled the adult cartilage.

The surface formed by a chondrosynovial membrane of typical composition was mostly uneven (Figs. 1, 3, 4, 5). There were only few small regions where short 
bundles of aperiodic filaments occurred. These lay at or immediately under the surface and ran parallel to the cartilage surface (Figs 1,3). In the surface layer, about $1 \mu \mathrm{m}$ thick, the aperiodic fibrils and collagen fibres were very dense and were oriented perpendicular to each other (Figs 3,4). Subjacent to this layer were various thick bundles of typical collagen fibrils lying parallel to the surface; they were found near the chondrocyte lacunae (Figs 3, 4). At 2 days after birth the lacunae were quite distinct. They consisted of a large amount of amorphous substance and of aperiodic fibrils transversing in various directions. The pericellular matrix with these characteristics was seen near the cartilage surface (Figs 3,4) while in the deeper part the typical pericellular matrix was not formed. In this zone the cell membrane was attached to the intercellular matrix composed of typical collagen fibrils varying in length which ran singly and produced an irregular mesh (Figs $2,3,4$ ). In the intercellular matrix the amorphous substance was in excess of the fibrillar component.

A different structure of intercellular matter was observed in the regions where the top surface chondrocytes underwent disintegration. Their debris were seen close to the articular surface (Fig. 5) deposited between aperiodic and collagen fibrils which penetrated into the areas of pericellular matrix from the surrounding intercellular matrix. They gradually filled up the whole lacuna. The remnants of cellular organelles and dark bodies may also have passed into the articular cavity from which they were removed by the action of synovialocytes or phagocytosis by chondrocytes. Around each degraded chondrocyte, the intercellular matrix showed a larger amount of fibrillar structures (Fig. 5) than did the rest of the matrix.

In the middle layer, chondrocytes were arranged into lacunae and the pericellular matrix could be well distinguished from the intercellular one. In some instances extrusion of aperiodic collagen fibrils by chondrocytes was observed (Fig. 8).

In the deep layer, the pericellular matrix was found to form only a thin lining (Fig. 9) or was not discernible at all (Fig. 10). Typical collagen fibrils, however, proliferated (Fig. 9) and penetrated as far as the close vicinity of the chondrocytes (Fig. 10).

\section{Discussion}

The structure of articular cartilage, at both microscopic and submicroscopic levels, has been studied thoroughly in man and small laboratory animals (for review see Ghadially 1983; Horký 1980). In farm animals the submicroscopic characteristics of this specialized tissue have received less attention (Horký $1983 ; 1984 ; 1986 ; 1988 ; 1989 \mathrm{ab})$. The articular cartilage in swine under physiological conditions has been dealt with by Nakano (1979 a, 1982), Wilsman et al. (1981), Bhatnagar (1981), Kincaid (1982). Some results have been published on the blood supply of the skeletal blastema and articular cartilage under physiological conditions and in relation to degenerative processes (Lavene 1964; Lufti 1970; Denecke and Trautwein 1986). Some biochemical studies were made by Simunek and Muir (1972). The behaviour of chondrocytes of porcine cartilage was reported by Burck and Lebowitz (1982) and Farnum et al. (1984). The effects of nutrition, sex and hormones on the occurrence of cartilaginous lesions have been studied by Nakano et al. (1979 b).

Practical reasons led to investigations into the histological changes associated with osteochondrosis and arthrosis in the pig (Grondalen 1987 a, b, c, d, e, f; 
Grondalen and Grondalen 1974; Grondalen and Vangen 1974; Doige 1980; Nakano et al. 1982; Denecke 1985).

The studies of the microscopic structure of articular cartilage had been largely focussed on its thickness and on the density and distribution of chondrocytes, particularly in the surface parts, in relation to the function of the joint (Simon 1970, 1071; Gilmore and Palfrey 1987, 1988). The latter authors were interested in the density of chondrocytes and the way they were distributed. Their findings were in agreement with the accepted view that the orientation of chondroblasts is conditioned by pressure forces acting on the cartilage. Gould et al. (1974), on the other hand, suggest that the chondroblast orientation is related to the production of intercellular matrix. They assume that chondrocytes are under pressure of a large amount of synthesized matter arising in a chondrification centre. This view can hold for the instance when mesenchymal blastema of the bone rudiment is generating a cartilage. However, the articular cartilage has no chondrification centre and it is itself too thin to allow such forces to function. A different factor, however, should not be overlooked; that is pressure on cartilage produced by muscles which develop before the articular fissure is formed. Probably both these factors are involved in the final arrangement of cartilage. Actions of these forces have great influence on the course and distribution of fibres in the intercellular matter. This and the amorphous substance are responsible for mechanical properties of articular cartilage, while the synthesis of these components is the major function of chondrocytes (Mainardi 1987; Fassbender 1987; Williams et al. 1988; Pelletier et et al. 1989).

An interesting and often discussed finding is the presence of blood vessels in articular cartilage (for review see Horký 1986, 1988). It has repeatedly been demonstrated that the vessels occur only in the early foetal period. Their finding in later stages always indicates a pathological state resulting from an inflammatory process.

Chondrocytes in the surface layer of the porcine articular cartilage had characteristics, i. e., appearance, size, orientation, similar to the cells of this type studied earlier in the corresponding periods in other mammals (Horký 1980, 1987). This applied particularly to the superficial cells. The cells lying deeper in the surface layer were different from those studied in other mammals in that they had a well-developed Golgi apparatus. This implies that the surface layer cells are involved in distributing components of the intercellular matter, if not directly in its synthesis. Of interest was a finding of low numbers of intracytoplasmic filaments in these cells; for instance bovine chondrocytes in the perinatal period contain numerous bundles of filaments (Horký 1987). Similar observations were made in our earlier work (Horký 1980, 1986). Also the appearance of the zonula nucleum limitans varies (Horký 1986, 1987); its width is changing in relation to the age and physiological conditions of the cells, which is in agreement with the literature data (Oryschak et al. 1974).

The most pronounced changes could be seen in the middle layer. Chondrocytes differentiated into the cells with all the ultrastructural characteristics of the cells generating intercellular matter. This was shown, first of all, by the amounts of the granular endoplasmic reticulum, mitochondria, Golgi apparatus and its derivatives. A part of this were also deposits of glycogen whose degradation manifested itself by multiplication of the structures of agranular endoplasmic reticulum and by production of vacuoles in glycogen deposits. However, it should not be assumed that a larger quantity of glycogen is a direct proof of synthesis. On the contrary, 
its accumulation in the cytoplasm of middle layer cells indicates insufficient utilization and reduction of synthesizing activity (Ghadially 1983). The view that this layer is significant for cartilage grow th in terms of metabolic activity is supported by our observations of collagen protofibrils with signs of periodicity passing through the cell membrane, and the regular presence of cilia. This phenomenon has already been noticed in our earlier studies of articular cartilage and synovial membrane in cattle and swine during their prenatal development (Horký 1983, 1986, 1988). The presence of lipid droplets in the cytoplasm of middle layer chondrocytes is a usual finding (e. g. see Ghadially 1983). In comparison with the articular cartilage in the prenatal period, particularly at the early stages (Horký 1988), the cartilage after birth was characterized by the appearance of slightly different cells in the zone between the middle and the deep layers. Such chondrocytes have not been found in other mammalian species (Horký 1983, 1986, 1988). The cytoplasm of deep layer chondrocytes is generally free of lipid droplets; our material, however, showed them quite often. A similar finding has been made by Silberger and Hasler (1975) in mice put on a long-term diet high in cholesterol.

Like the cells, the intercellular matter undergoes further differentiation, both in quantity and quality, in the period after birth. In terms of joint functioning, the most important role is assumed by the surface layer. At the early stages after fertilization, this is mainly composed of aperiodic fibrils and abundant amorphous substance. With progressing prenatal development its structure becomes more complex and near the term the articular cartilage, and it surface layer in particular, gradually attain properies enabling smooth movement of the newborn pig's joints. In the cartilage studied here, the bundles of aperiodic filaments on or immediately under the surface were found on rare occasions. A layer of about $1 \mu \mathrm{m}$ thick, however, shows a marked increase in collagen fibrils which run perpendicular to each other thus rendering this layer an architecture similar to that found in the cartilage of cattle at the same age (Horky 1987). The chondrosynovial membrane, as observed in the period under study, is completely developed and fully involved in joint movement (Maroudas 1974; Wolf 1975; Ghadially 1983). Compared to earlier stages of ontogeny (Horký 1988) the surface and middle layers in this period showed distinct and the deep layer less distinct pericellular and intercellular matrix.

\section{Submikroskopická struktura kloubní chrupavky prasete v časném období po narození}

Byla studována kloubní chrupavka kyčelního kloubu 4 jedinců prasete obojího pohlaví stáři 2 dne po narození. Vzorky tkáně byly zpracovány pro účely světelné, transmisní a rastrovací elektronové mikroskopie obvyklým zpưsobem.

Povrchová vrstva je tvořena vřetenovitými chondrocyty uloženými ve dvou řadách. Chondrocyty vysílají dlouhé výběžky do okolní mezibuněčné hmoty, která je rozlišena na pericelulární a intercelulární matrix. Nápadný je dobře rozvinutý Golgiho aparát a cytoplasmatické inkluze.

Chondrocyty středni vrstvy jsou oválné buňky velikosti $9 \times 6 \mu \mathrm{m}$. Obsahuji větší množství cytoplasmy, Golgiho aparát je rozložen do několika polí, četné mitochondrie, hojné granulární endoplasmatické retikulum, glykogen a lipidové kapénky. Významné jsou četné transportní vakuoly. $V$ této vrstvě jsme pozorovali 
pravidelně cilie a zachytili jsme prostup kolagenních protofibril buněčnou membránou. Je zřetelně odlišena pericelulární a intercelulární matrix.

Na přechodu střední do hluboké vrstvy jsme pozorovali přechodné typy chondrocytů. Buňky hluboké vrstvy jsou seřazeny do sloupců kolmo k povrchu a neodlišují se od chondrocytů stejné vrstvy dospělých jedinců.

$\mathrm{Na}$ povrchu chrupavky $\mathrm{v}$ tomto období je již vytvořena chondrosynoviální membrána. Pod ní v hloubce asi $1 \mu \mathrm{m}$ jsou uloženy kolagenní fibrily kolmo na sebe a vytvářejí tak povrchovou vrstvu schopnou snášet tlak a zabezpečovat pohyb kloubu.

\section{Сүбмикроскопическая стрүктүра сүставного хряща поросят В ранний период поспе рождения}

Проводили исследования сүставного хряща тазобедренного сустава 4 особей поросят обоего пола в возрасте 2 суток после рождения. Образцы ткани обрабатывали для световой, трансмиссионной и растровой электронной микроскопии обычным способом.

Поверхностный слой состоит из расположенных двумя рядами веретенообразных хондроцитов. В окружение межклеточной массы хондроциты выходят длинными выступами. Межклеточная масса дифференцирована на перицеллюлярный и интерцеллюлярный слой. Весьма хорошо развиты аппарат Гольджи и цитоплазматические инклюзии.

Хондроциты среднего слоя состоят из клеток овальной формы размером $9 \times 6$ мкм. Они содержат большее количество цитоплазмы, аппарат Гольджи расположен в нескольких участках, многочисленные митохондрии, гранулярный эндоплазматический сетчатый слой, гликоген и липидные капельки. Важными являются многочисленные транспортные вакуоли. В данном слое наблюдали регулярно реснички и установили прохождение коллагенных протофибрилл клеточной мембраной. Наблюдается четкое различие перицеллюлярного и межклеточного споев.

На рубеже среднего и глубокого слоев наблюдали переходные типы хондроцитов. Клетки глубокого слоя образуют колонки вертикально к поверхности и не отличаются от хондроцитов одинакового слоя взрослых особей.

На поверхности хряща в данный период сформирована уже хондросиновиальная мембрана. Ниже, приблизительно 1 мкм, расположены коллагенные фибриллы перпендикулярно, образуя таким способом поверхностный слой, стойкий к давлению и обеспечивающий движение сустава.

\section{References}

BARNETT, C. H. - COCHRANE, W.-PALFREY, A. J.: Age changes in articular cartilage of rabbits. Ann. rheum. Dis., 22, 1963: 389-400

BHATNAGAR, R. - CHRISTIAN, R. G.-NAKANO, T.-AHERNE, F. X.-THOMPSON, J. R.: Age related changes and osteochondrosis in swine articular and epiphyseal cartilage: Light and electron microscopy. Can. J. Comp. Med., 45, 1981: 188-195

BLOEBAUM, R. D.-WILSON, A. S.: The morphology of the surface of articular cartilage in adult rats. Am. J. Anat., 131, 1980: 333-346 
BONUCCI, E.: Fine structure of early cartilage calcification. J. Ultrastruct. Res., 20, 1967: $33-45$

BURCH, W. M.-LEBOVITZ, H. E.: Triiodothyronine stimulates maturation of porcine growth - plate cartilage in vitro. J. Clin. Invest., 70, 1982: 496-504

CLARKE, I. C.: Articular cartilage: a review and scanning electronmicroscope study. II. The territorial fibrillar architecture. J. Anat. (Lond.), 118, 1974: 261-280

DAVIES, D. V.-BARNETT, C. H.-COCHRANE, W.-PALFREY, A. J.: Electron microscopy of articular cartilage in the young adult rabbit. Ann. rheum. Dic., 21, 1962: 11-22

DENECKE, R.-KAUP, F. J.-MEYER, M.: Intercellular network in articular cartilage of pigs with experimentally induced arthritis. I. Fact or artifact? Rheumatol. Int., 576, 1985: $265-271$

DENECKE, R. - TRAUTWEIN, G.: Articular cartilage canals - a new pathogenetic mechanism in infectious arthritis. Engl. Experientia, 42, 1986: 999-1 001

DOIGE, C. E.: Pathological changes in the lumbar spine of boars. Can. J. comp. Med., 44, 1980: $382-389$

FARNUM, C. E. - WILSMAN, N. J. - HILLEY, H. D.: An ultrastructural analysis of osteochondritic growth plate cartilage in growing swine. Vet. Pathol., 21, 1984: 141-151

FASSBENDER, H. G.: Role of chondrocytes in the development of osteoarthritis. Engl. Am. J. Med., 85/5 A, 1987: 17-24

FREEMAN, M. A. R. - KEMPSON, G. E.: Load carriage. In: Adult articular cartilage, pp. 228-246, M. A. R. Freeman (ed.), Alden Press, Oxford, Great Britain, 1973

FIFE, R. S.: Comparison of a $\mathbf{5 5 0 . 0 0 0}$ dalton cartilage matrix glycoprotein in cartilage from immature and mature dogs. J. Rheumatol., 16, 1989: 656-660

GARDNER, E.-O'RAHILLY, R.: The early development of the knee joint in staged human embryos. J. Anat. (Lond.), 102, 1968: 289-299

GHADIALLY, F. N.: Structure and function of articular cartilage. Clin. rheum. Dis., 7, 1981: 3-28

GHADIALLY, F. N.: Fine structure of synovial joints. Butterworths, London 1983

GILMORE, R. ST. C.-PALFREY, A. J.: A histological study of human femoral condylar articular cartilage. Am. J. Anat., 155, 1987: 77-85

GILMORE, R. ST. C.-PALFREY, A. J.: Chondrocyte distribution in the articular cartilage of human femoral condyles. Am. J. Anat., 157, 1988: 23-31

GOULD, R. P.-SELWOOD, L.-DAY, A.: The mechanism of cellular orientation during early cartilage formation in the chick limb and regenerating amphibian limb. Exp. Cell Res., 83, 1974: 287-296

GRONDALEN, T.: Osteochondrosis and arthrosis in pigs. I. Incidence in animals up to $120 \mathrm{~kg}$ live weight. Acta vet., Scand., 15, 1974a: 1-25

GRONDALEN, T.: Osteochondrosis and arthrosis in pigs. II. Incidence in breeding animals. Acta Vet. Scand., 15, 1974b: 26-42

GRONDALEN, T.: Osteochondrosis and arthrosis in pigs. III. A comparison of the incidence in young animals of the Norwegian Landrace and Yorkshire breeds. Acta Vet. Scand., 15, 1974c: $43-52$

GRONDALEN, T.: Osteochondrosis and arthrosis in pigs. VI. Relationship to feed level and calcium, phosphorus and protein levels in the ration. Acta Vet. Scand., 15, 1974d: 147-169

GRONDALEN, T.: Osteochondrosis and arthrosis in pigs. VII. Relationship to ioint shape and exterior conformation. Acta Vet. Scand., 15, (Suppl. 46), 1974e: 1-32

GRONDALEN, T.: Osteochondrosis, arthrosis and leg weakness in pigs. Nord. Vet. Med., 26, 1974f: $534-537$

GRONDALEN, T. - GRONDALEN, J.: Osteochondrosis and arthrosis in pigs. IV. Effect of overloading on the distal plate of the ulna. Acta Vet. Scand., 15, 1974: 53-60

GRONDALEN, T. - VANGEN, O.: Osteochondrosis and arthrosis in pigs. V. Comparison of the incidence in three different lines of the Norwegian Landrace Breed. Acta Vet. Scand., 15, 1974: $61-79$

HANAOKA, H.: The fate of hypertrophic chondrocytes of the epiphyseal plate. An electron study. J. Bone Jt Surg. 58, 1976: 226-229

HORKYY, D.: Submicroscopic structure of the human joint cartilage. Acta vet. Brno, 49, 1980: $145-176$

HORKÝ, D.: Ontogenic development of the ultrastructure of bovine joint cartilage. Acta vet. Brno, 52, 1983: 103-13n

HORKY, D.: Ultrastructure of bovine articular cartilage between weeks 8 and 23 of prenatal development. Acta vet. Brno, 55, 1986: 227-246

HORKÝ, D.: Submicroscopic structure of bovine articular cartilage in prenatal and early postnatal period. Acta vet. Brno, 56, 1987: 3-18 
HORKÝ, D.: The ultrastructure of articular cartilage in the prenatal pig. Acta vet. Brno, 58, 1988: $143-174$

HORKY, D.: Submicroscopic structure of articular cartilage in human embrya six to eleven weeks old. Acta vet. Brno, 60, 1991: 15-30

HORKÝ, D.: Submicroscopic structure of human articular cartilage in the period between 19 to 38 weeks after fertilization. Acta vet. Brno, 60, 1991: 111-126

CHAPPUIS, J. - SHERMAN, I. A. - NEUMANN, A. W.: Surface tension of animal cartilage as it relates to function in ioints. Anm. Biomed. Eng. 11, 1983: 435-451

KIEFER, G. N. - SUNDBY, K. - MCALLISTER, D.-SHRIVE, N. G.-FRANK, C. B.LAM, T. - SCHACHAR, N. S.: The effect of cryopreservation on the biomechanical behavior of bovine articular cartilage. J. Orthop. Res., 7, 1989: 494-502

KINCAID, S. A.-LIDVALL, M. S.: Communicating cartilage canals of the physis or the distal part of the ulna of growing swine and their potential role in healing of metaphyseal dysplasia of osteochondrosis. Am. J. Vet. Res., 43, 1982: 938-944

LEVENE, C.: The pattern of cartilage canals. J. Anat. (Lond.), 98, 1564: 515-538

LUFTI, A. M.: The mode of growth, fate and function of cartilage canals. J. Anat. (Lond.), 106, 1970: $135-145$

LUST, G.-PRONSKY, W.-SHERMAN, D.: Biochemical and ultrastructural observations in normal and degenerative canine articular cartilage. Am. J. Vet. Res., 33, 1972: 2 427-2 440

LUST, G. - SHERMAN, D. M.: Metabolic and ultrastructural studies on articular cartilage of developing canine hip joints. Cornell Vet., 63, 1973: 94-104

MAINARDI, C. L.: Biochemical mechanisms of articular destruction. Rheum. Dis. Clin. North Am., 13, 1987: 215-233

MARK, M. P.-BUTLER, W. T.-RUCH, J. V.: Transient expression of chondroitin sulfate-related epitope during cartilage histomorphogenesis in the axial skeleton of fetal rats. Develop. Biol., 133, 1989: 475-489

MAROUDAS, A.: Physico-chemical properties of articular cartilage. In: Adult articular cartilage. M. A. R. Freeman, Alden Press, Oxford, 1973

NAKANO, T.-AHERNE, F. X. - THOMPSON, J. R.: Changes in swine knee articular during growth. Can. J. Anim. Sci., 59, 1979a: 167-179

NAKANO, T.- AHERNE, F. X.-THOMPSON, J. R.: Effects of feed restriction, sex and diethylstilbestrol on the occurrence of joint lesions with some histological and biochemcial studies on the articular cartilage of growing-finishing swine. Can. J. Anim. Sci., 59, 1979b: $491-502$

NAKANO, T.-THOMPSON, J. R.-AHERNE, F. X.: Molecular size of chondroitin sulfate from normal and osteochondritic joint cartilage of adolescent boars. Can. J. comp. Med., 46, 1982: $395-399$

NEAME, P. J.-CHOI, H. U.-ROSENBERG, L. C.: The primary structure of the core protein of the small, leucine- rich proteoglycan (PG I) from bovine articular cartilage. J. Biol. Chem. 264, 1989: 8646-8653

O'CONNOR, P.-BRERETON, J. D.-GARDNER, D. L.: Hyaline cartilage disected by papain-light and scanning electron microscopy and micromechanical studies. Ann. rheum. Dis., 43, 1984: $320-327$

ORYSCHAK, A. F.-GHADIALLY, F. N.-BHATANAGAR, R.: Nuclear fibrous lamina the chondrocytes of articular cartilage. J. Anat. (Lond.), 118, 1974: 511-515

PALMOSKI, M. J.-BRANDT, K. D.: Effects of static and cyclic compresive loading on articular cartilage plugs in vitro. Arthritis Rheum., 27, 1984: 675-682

PELLETIER, J. P.-CLOUTIER, J. M.-MARTELPELLETIER, J.: In vitro effects of tiaprofenic acid, sodium salicylate and hydrocortison on the proteoglycan metabolism of human osteoarthritic cartilage. J. Rheumatol., 16, 1989: 646-655

PERRIN, W. R.-AHERNE, F. X.-BOWLAND, J. P.-HARDIN, R. T.: Effects of age, breed and floor type on the incidence of articular cartilage lesions in pigs. Can. J. Anim. Sci., 58, 1978: $129-138$

SILBERGER, R. - SILBERGER, M. - VOGEL, A.-WETTSTEIN, W.: Ultrastructure of articular cartilage of mice of various ages. Am. J. Anat., 109, 1961: 251-275

SILBERGER, R.-HASLER, M.: Submicroscopic response of articular chondrocytes to a cholesterol-containing diet. Pathol. Microbiol. (Basel), 43, 1975: 276-286

SILBERGER, R. - HASLER, M. - LESKER, P.: Ultrastructure of articular cartilage of achondroplastic mice. Acta Anat. (Basel), 96, 1976: 162-175

SIMON, W. H.: Scale effects in animal joints. I. Articular cartilage thickness and compressive stress. Arthritis Rheum., 12, 1970: 244-256

SIMON, W. H.: Scale effects animal joints. II. Thickness and elasticity in the deformability of articular cartilage. Arthritis Rheum., 14, 1971: 493-502 
SIMUNEK, Z. - MUIR, H.: Proteoglycans of the knee joint cartilage of young normal and lame pigs. Biochem. J., 130, 1972: $181-187$

STOCKWELL, R. A.: The cell density of human articular and costal cartilage. J. Anat. (Lond.), 101, 1967: 753-763

WEISS, C.-ROSENBERG, L.-HELFET, A. J.: An ultrastructural study of normal young adult human articular cartilage. J. Bone Jt. Surg., 50A, 1968: 663-674

WILIAMS, J. M.-KATZ, R. J.-CHILDS, D.: Keratan sulfate content in the superficial and deep layers of osteophytic and nonfibrillated human articular cartilage in osteoarthritis. Calcif. Tissue Int., 42, 1988: 162-166

WILSMAN, N. J.-FARNUM, C. E.-HILLEY, H. D.-CARISEN, C. S.: Ultrastructural evidence of a functional heterogeneity among physeal chondrocytes in growing swine. Am. J. Vet. Res., 42, 1981: $1547-1553$

WILTBERGER, H.-LUST, G.: Ultrastructure of canine articular cartilage: comparison of normal and degenerative (osteoarthritic) hip joints. Am. J. Vet. Res., 36, 1975: 727-740

WOLF, J.: Function of chondral membrane on surface of articular cartilage from point of view of its mechanical resistance. Folia morphol. (Prague), 23, 1975: 77-87

WRIGHT, V.: Lubrication and wear in joints. Sector Publ. Lim., London, 1969 
Plate VII.

Horký D.: The Submicroscopic... pp. 323-334

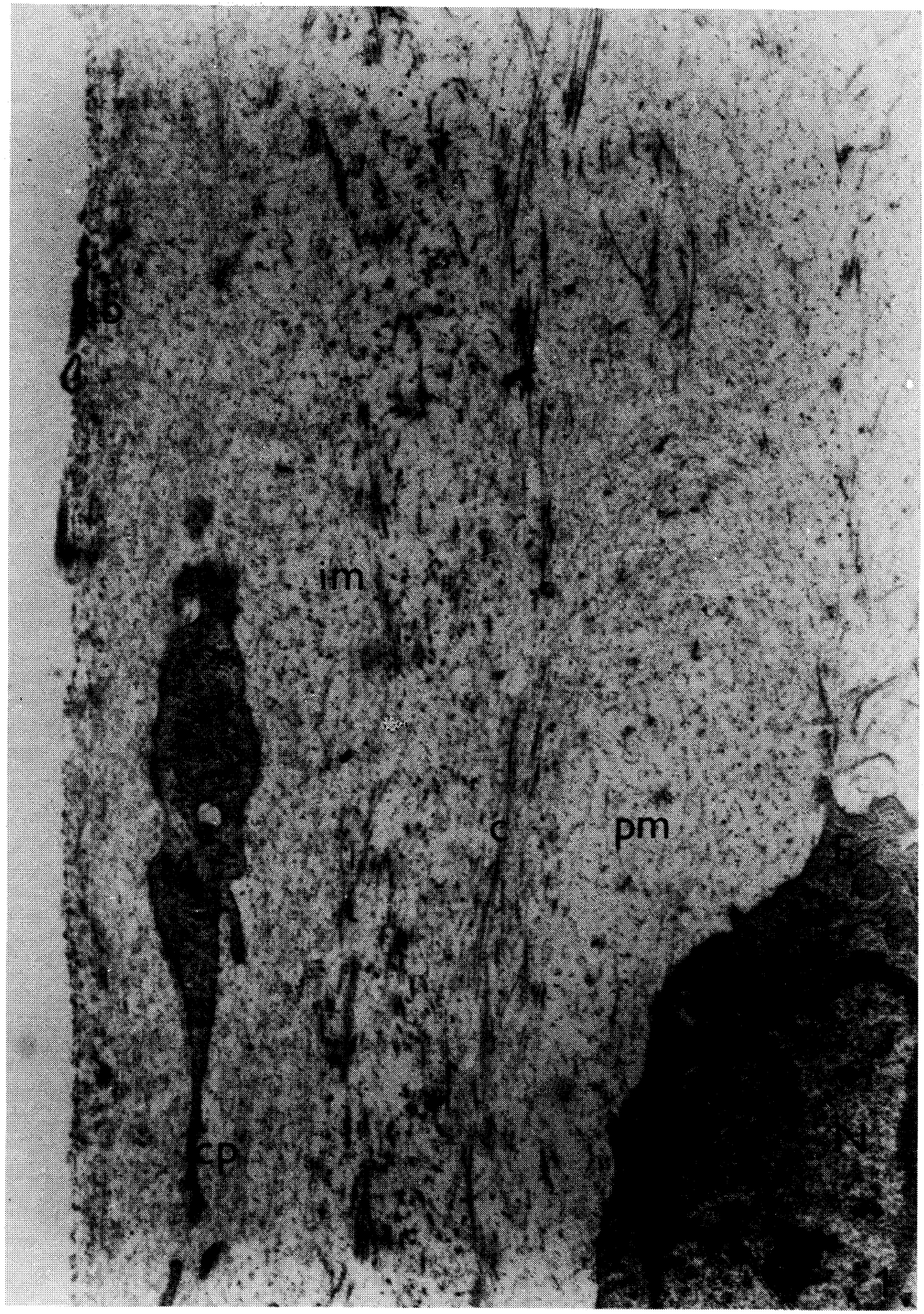

Fig. 1. The superficial layer of articular cartilage. A chondrocyte with the nucleus $(\mathrm{N})$, granular endoplasmic reticulum (E), mitochondria (M), long projection of cytoplasm (cp). On the surface, infrequent bundles of aperiodic filaments $(\mathrm{ab})$. Pericellular matrix $(\mathrm{pm})$, intercellular matrix (im) with collagen fibrils (c). $\times 16000$. 


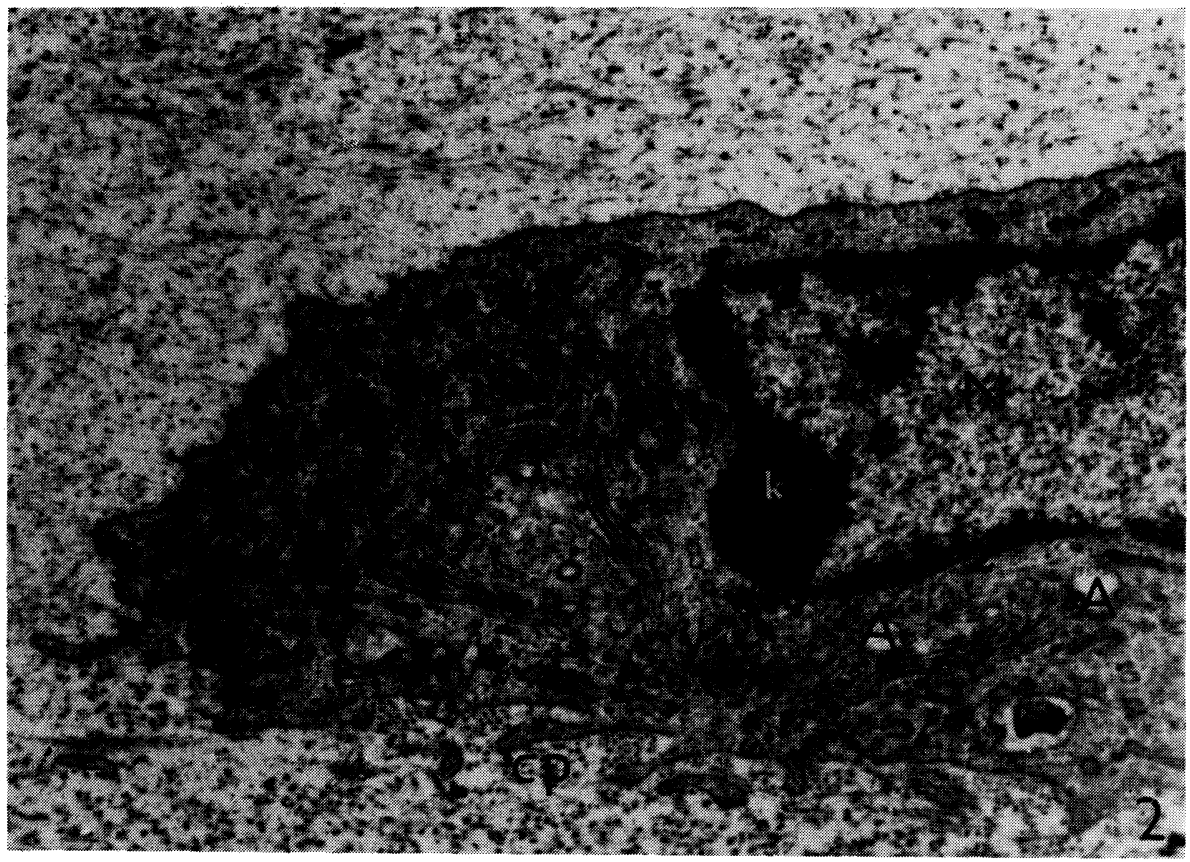

Fig. 2. A part of the cytoplasm of a surface layer chondrocyte. Nucleus (N), karyosomes (k), zonula nucleum limitans (z). Granular endoplasmic reticulum (E), agranular endoplasmic reticulum (A). Golgi apparatus in several fields (G), small vesicles (v), transport vacuoles (tv), mitochondria (M), short projections (cp). $\times 18000$.

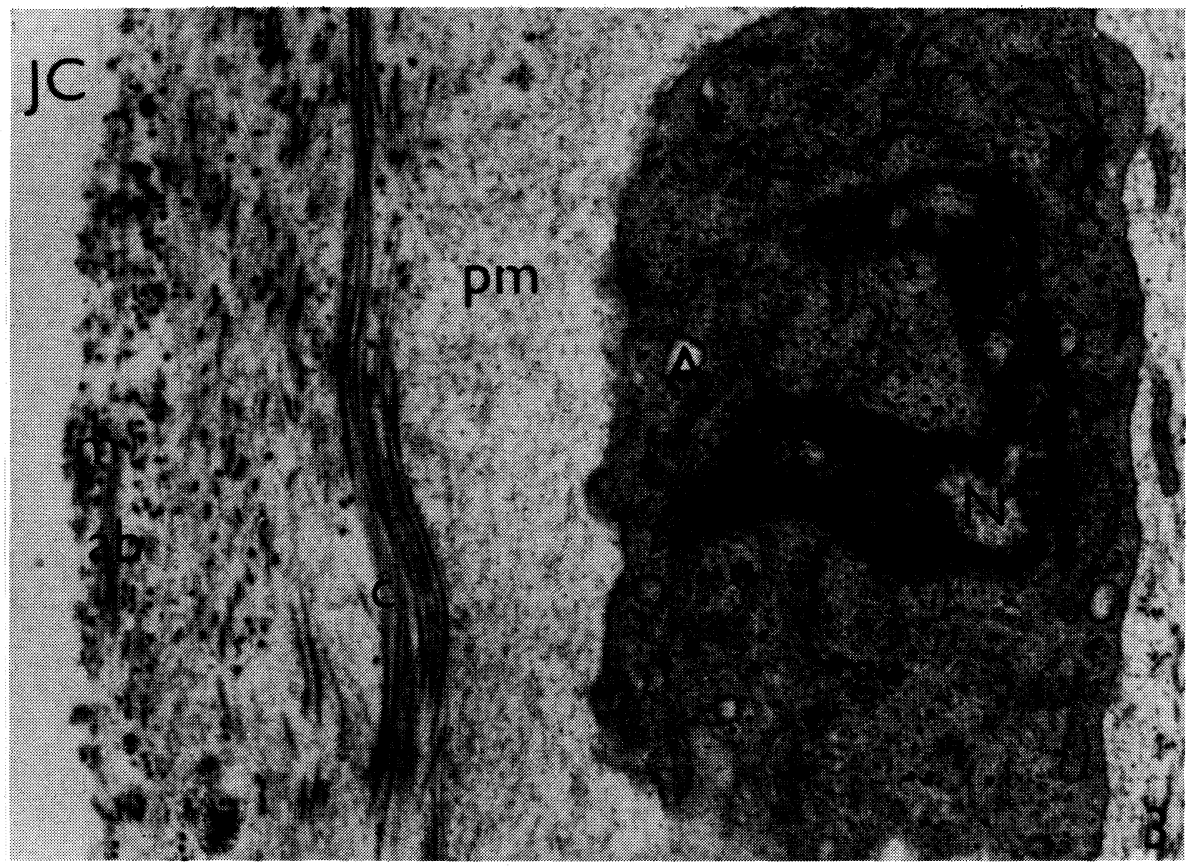

Fig. 3. The surface of articular cartilage with a chondrosynovial membrane (m), small bundles of aperiodic filaments $(\mathrm{ab})$, typical collagen fibrils $(\mathrm{c})$. The nucleus $(\mathrm{N})$ in the cytoplasm of a chondrocyte. Short cisternae of granular endoplasmic reticulum (E), vacuoles of agranular endoplasmic reticulum (A), small clusters of glycogen (g), mitochondria (M). A thick pericellular matrix with a network of aperiodic filaments (pm). Joint cavity (JC). x 18000 . 


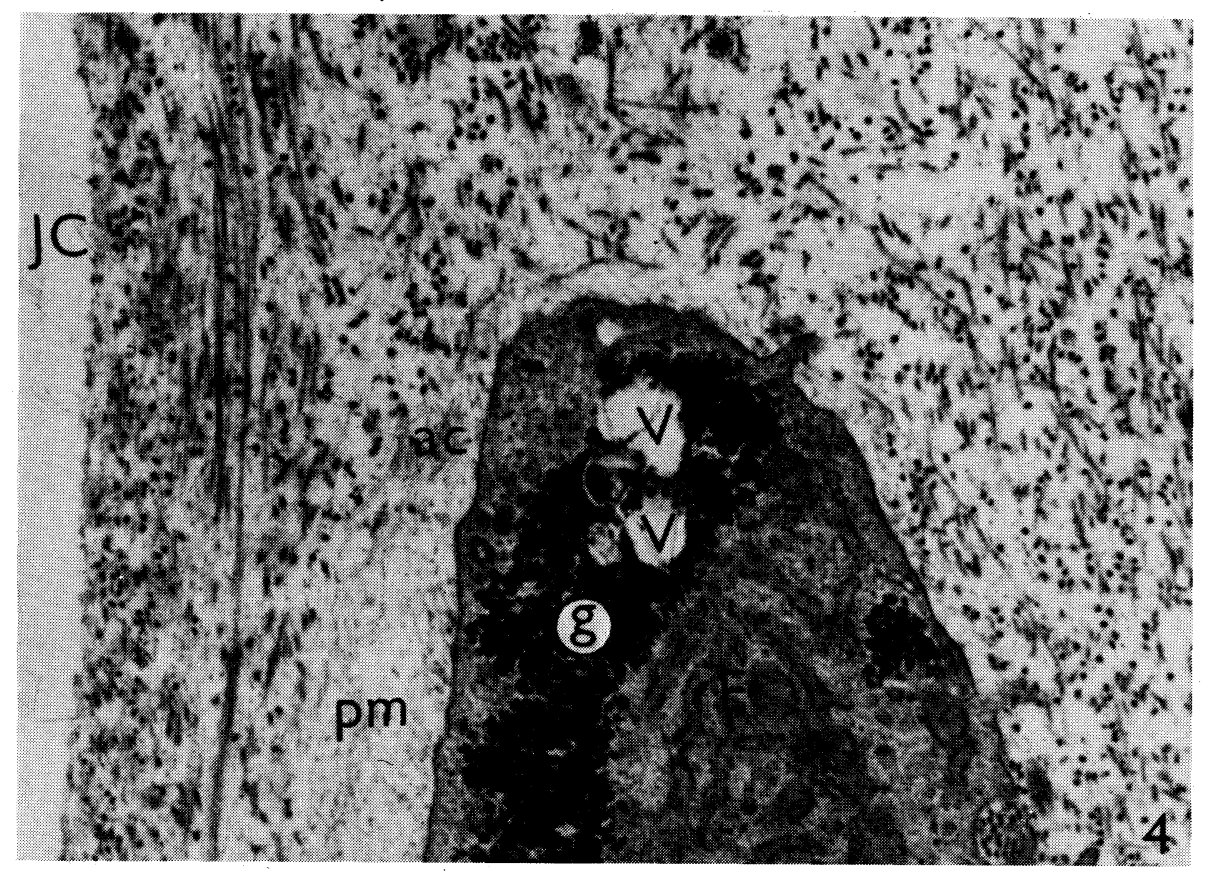

Fig 4. The cytoplasm of a chondrocyte in a different part of the articular cartilage surface. Many profiles of granular endoplasmic reticulum (E) with medium electron-dense material. Large deposits of glycogen $(\mathrm{g})$, resorbing vacuoles $(\mathrm{V})$. Pericellular matrix $(\mathrm{pm})$ is found only close to the surface. Aperiodic collagen fibrills (ac) in the vicinity of the cell membrane. Joint cavity (JC). $\times 18000$.

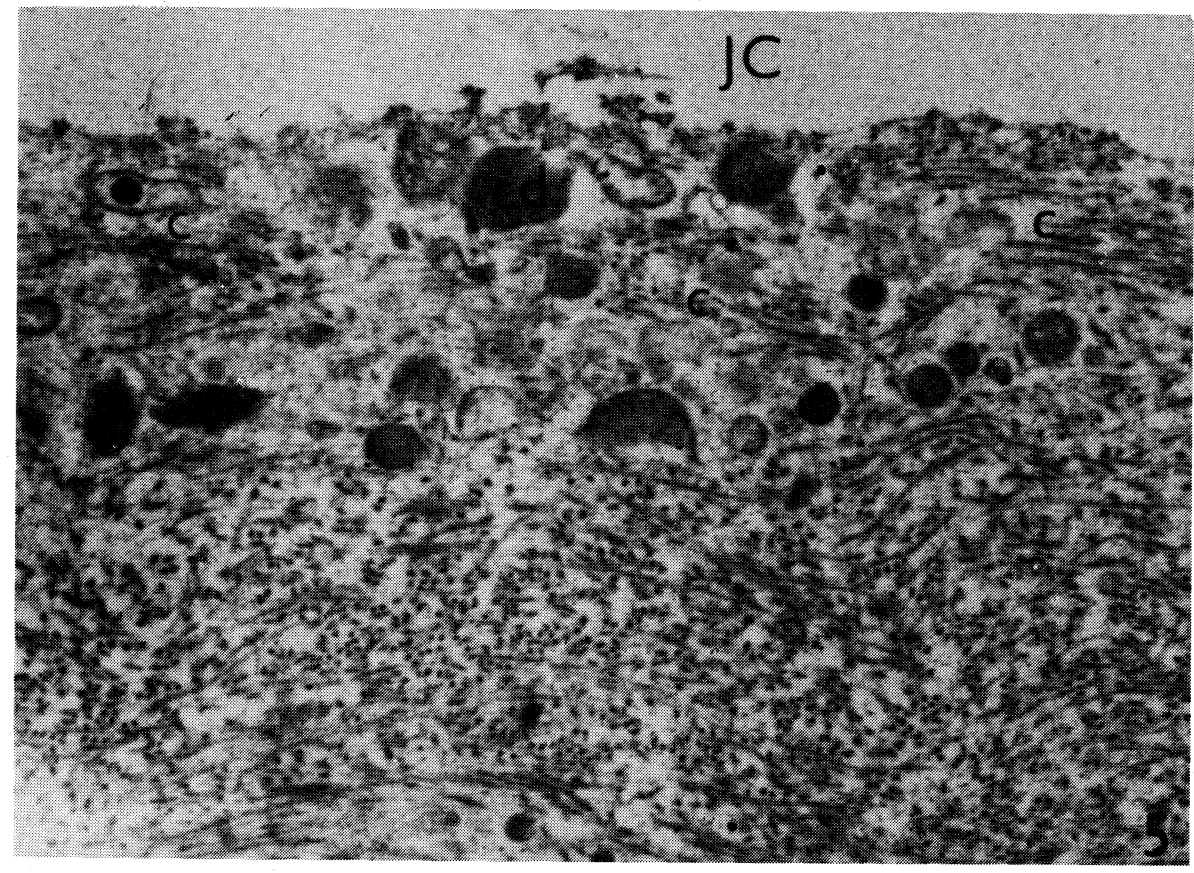

Fig. 5. The superficial layer of articular cartilage. Numerous collagen fibrils (c) below the debris of degraded chondrocytes (cd). The pericellular matrix is replaced with the intercellular matrix. Joint cavity (JC). x 18000 . 
Plate X.

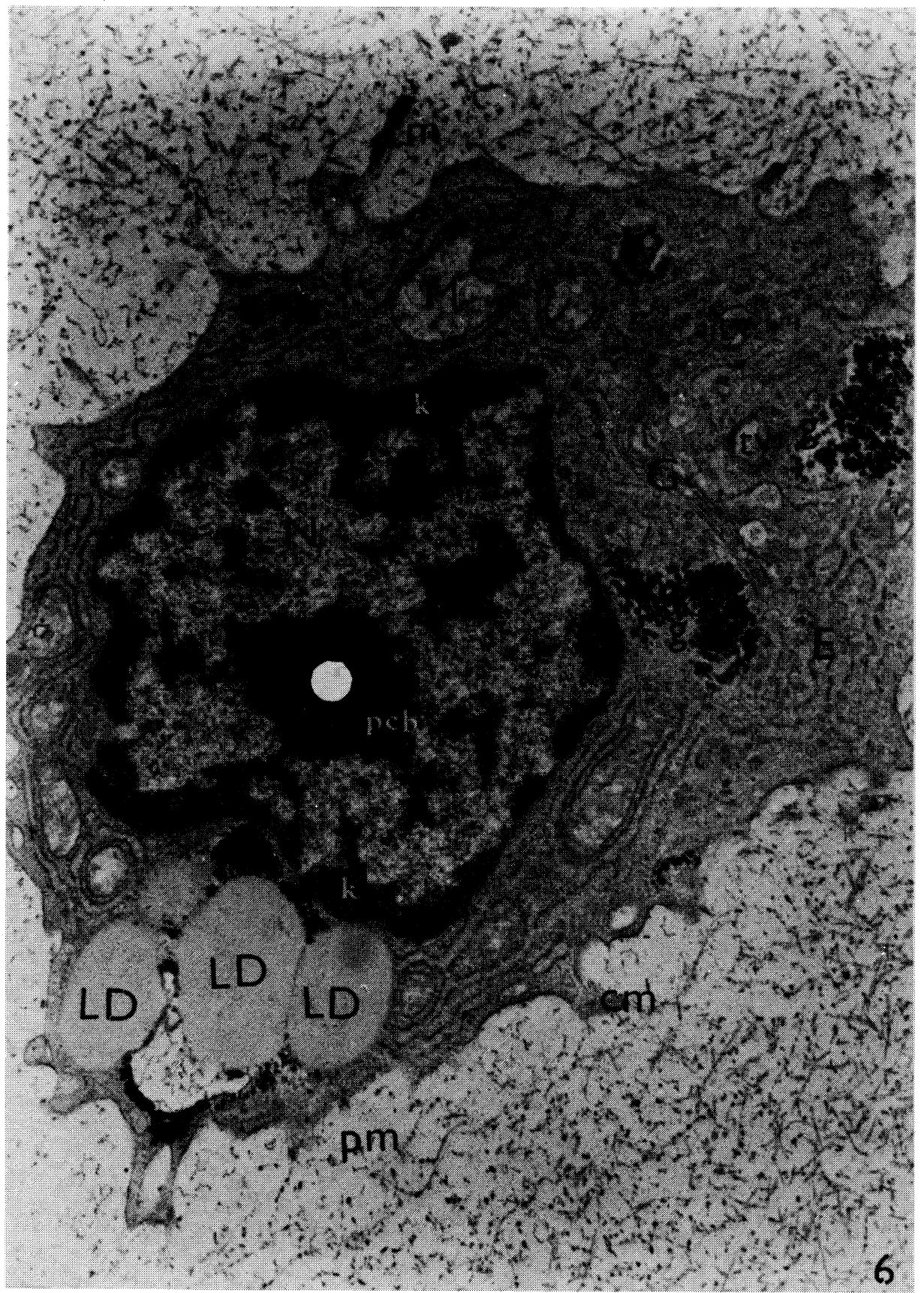

Fig. 6. A chondrocyte of the middle layer. Nucleus $(\mathrm{N})$, nucleolus $(\mathrm{n})$, karyosomes $(\mathrm{k})$, perinucleolar chromatin (pch). Numerous profiles of granular endoplasmic reticulum $(\mathrm{E})$, mitochondria with pale matrix $(\mathrm{M})$, large Golgi apparatus $(\mathrm{G})$, transport vacuoles (tv). Clusters of glycogen $(\mathrm{g})$, lipid droplets $(\mathrm{LD})$, cytoplasmic protrusions $(\mathrm{cm})$, pericellular matrix $(\mathrm{pm}) . \times 16000$. 


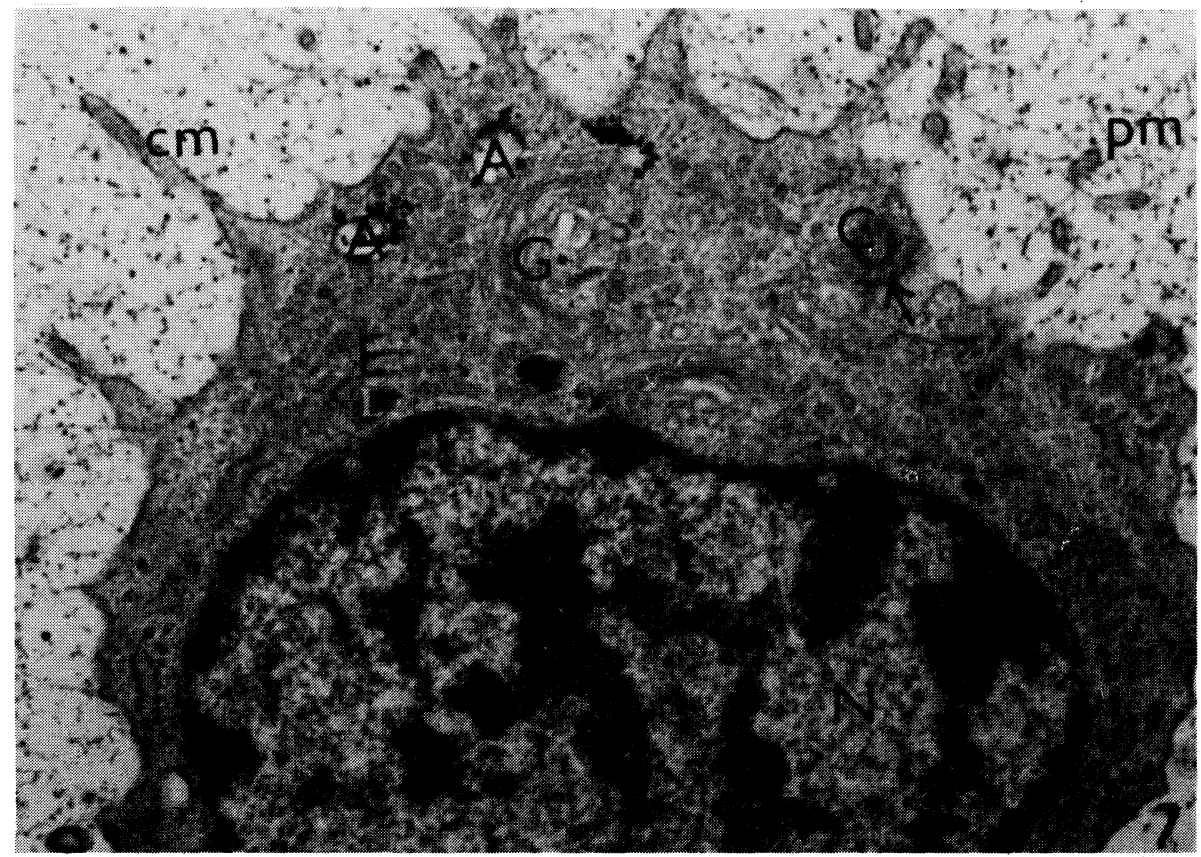

Fig. 7. A part of the nucleus (N) and cytoplasm of a middle layer chondrocyte. The nucleus does not differ from those in the previous pictures. The cytoplasm contains the Golgi apparatus distributed in several fields $(\mathrm{G})$, cisternae of granular endoplasmic reticulum (E), agranular endoplasmic reticulum (A) degrading into clusters of glycogen. Lysosomes (L), centrioles (C) with probably satelite structures in their vicinity $(\rightarrow)$. Cytoplasmic protrusions $(\mathrm{cm})$, aperiodic fibrils of pericellular matrix $(\mathrm{pm}) . \times 18000$.

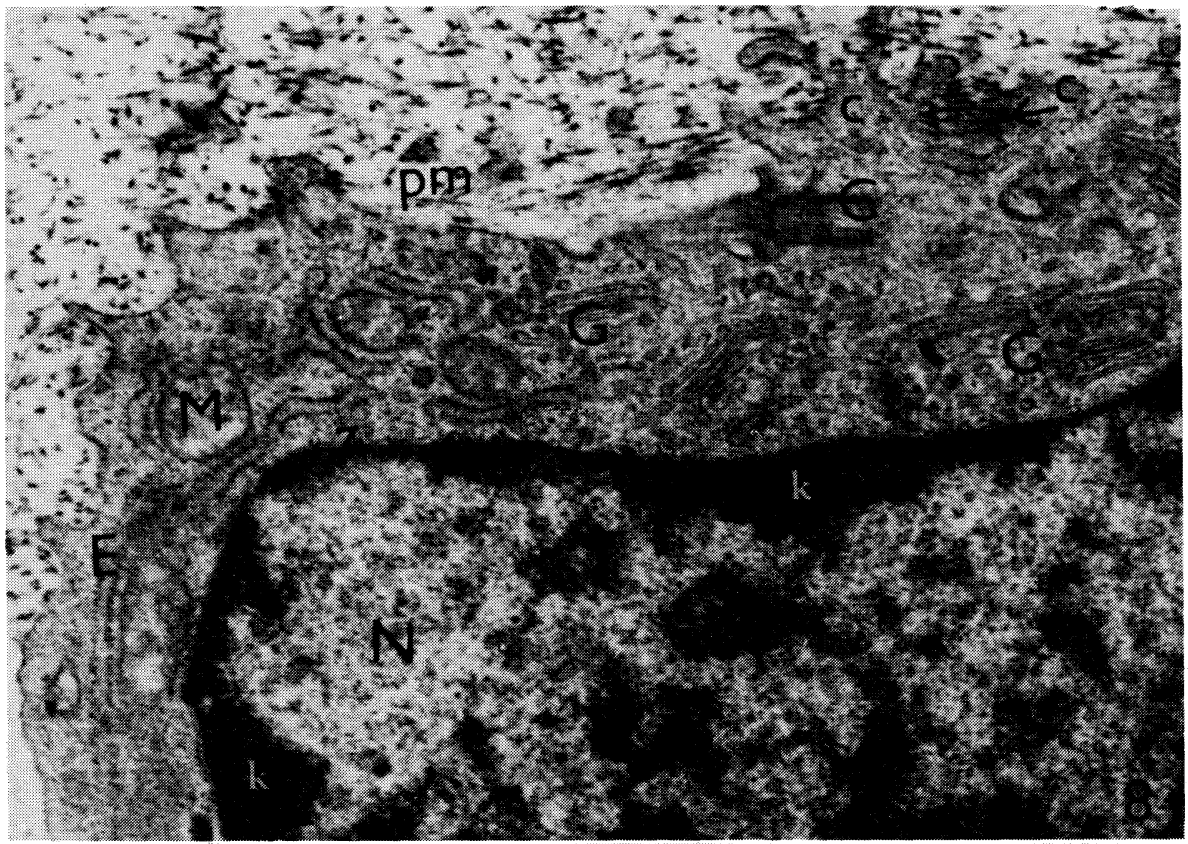

Fig. 8. A part of a middle layer chondrocyte. Nucleus $(\mathrm{N})$, karyosomes $(\mathrm{k})$, zonula nucleum limitans $(\mathrm{z})$. Granular endoplasmic reticulum (E), Golgi apparatus in several fields (G), mitochondria (M), centrioles (C). Passage of collagen fibrils through the cell membrane $(\rightarrow)$ between cytoplasmic protrusions (c). Aperiodic fibrils in pericellular matrix (pm). $\times 18000$. 


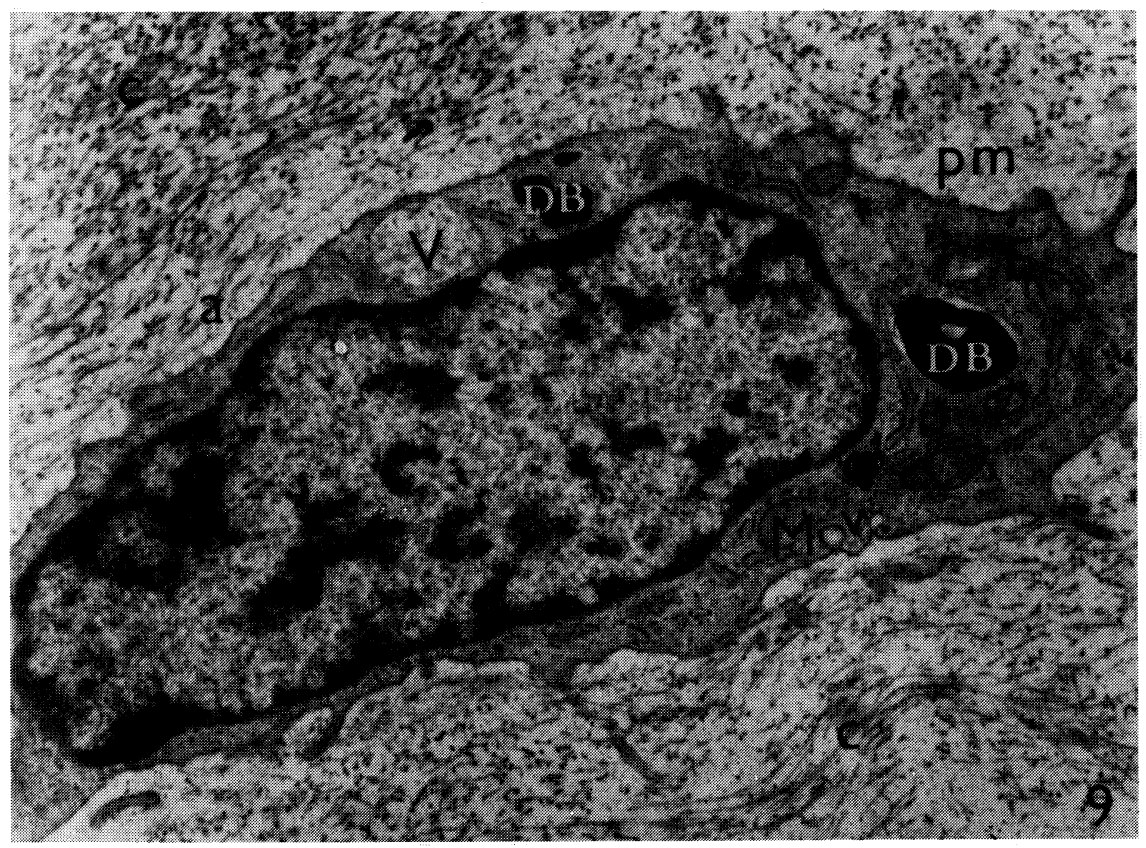

Fig. 9. A chondrocyte of the deep layer. The nuclear structure is similar to that found in Fig. 8 . The cytoplasm contains short profiles of granular endoplasmic reticulum (E). Mitochondria (M), rare pinocytotic vesicles (v) and large vacuoles with flocculated (V) or very dense (DB) materials. Pericellular matrix present only in the vicinity of the cell membrane (pm). Intercellular matrix contains both aperiodic (a) and typical collagen (c) fibrils. $\times 16000$.

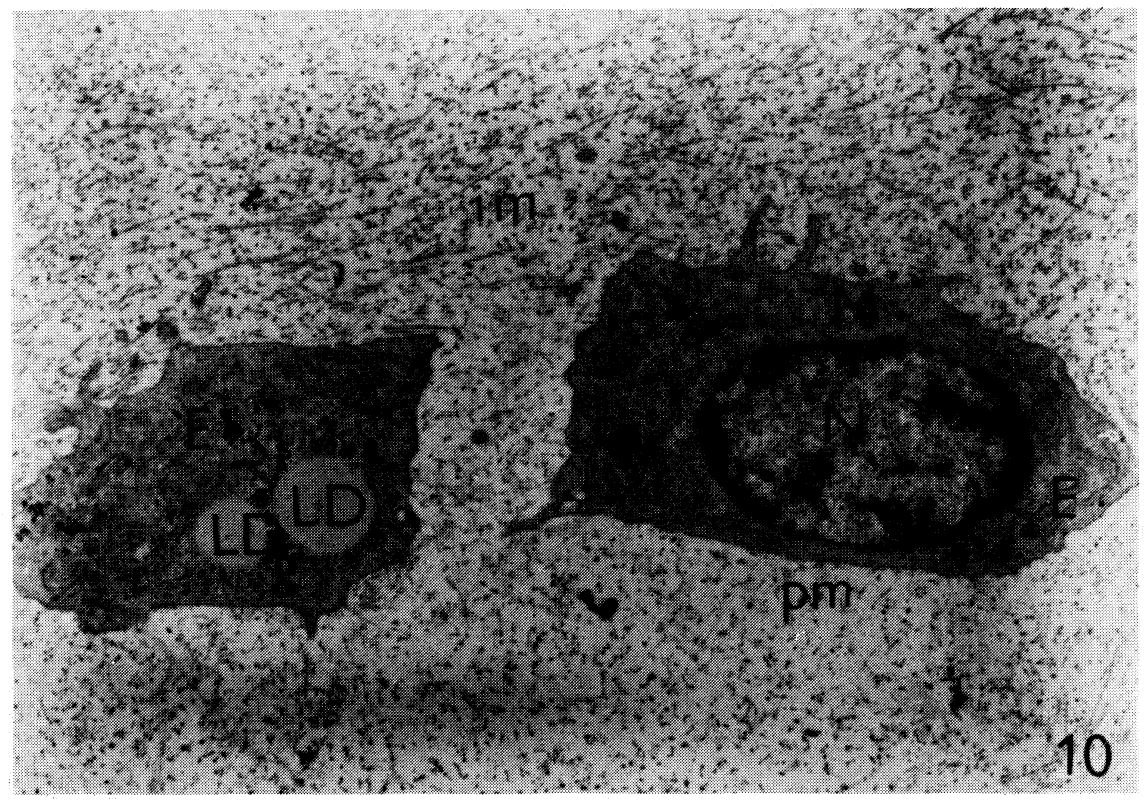

Fig. 10. A pair of chondrocytes in the deep layer. Nucleus $(\mathrm{N})$, granular endoplasmic reticulum (E), mitochondria (M), clusters of glycogen granules (g), lipid droplets (LD). Intercellular matter shows signs of differentiation into pericellular (pm) and intercellular (im) matrix. $\times 9000$. 